\title{
The Impact of Single Low Dose IV Magnesium Sulphate Adjuvant to Ultrasound Guided Transverses Abdominis Plain Block for Control of Postcesarean Pain
}

\author{
Tamer Nabil Abd Elrahman1, Mohamed Abdelaziz Youssry ${ }^{2 *}$ \\ ${ }^{1}$ Anesthesia and Intensive Care and Pain Department, Faculty of Medicine, Ain Shams University, Cairo, Egypt \\ ${ }^{2}$ Obstetrics and Gynecology Department, Faculty of Medicine, Alexandria University, Alexandria, Egypt

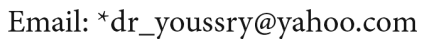

How to cite this paper: Elrahman, T.N.A. and Youssry, M.A. (2017) The Impact of Single Low Dose IV Magnesium Sulphate Adjuvant to Ultrasound Guided Transverses Abdominis Plain Block for Control of Postcesarean Pain. Open Journal of Obstetrics and Gynecology, 7, 269-280. https://doi.org/10.4236/ojog.2017.73029

Received: February 3, 2017

Accepted: March 12, 2017

Published: March 15, 2017

Copyright $\odot 2017$ by authors and Scientific Research Publishing Inc. This work is licensed under the Creative Commons Attribution International License (CC BY 4.0).

http://creativecommons.org/licenses/by/4.0/ (c) (i) Open Access

\begin{abstract}
Objective: The aim of this study is to determine the role of preoperative low dose intravenous $\mathrm{MgSO}_{4}$ when given adjuvant to ultrasound guided transversus abdominis plane (TAP) block in augmenting postcesarean analgesic effects and reducing opioid requirements during the first 24 hours. Subjects and Methods: In this prospective, randomized double blind study, a total of sixty full term pregnant women were recruited for the study underwent caesarean section. Thirty patients were assigned to $\mathrm{MgSO}_{4}$ group (A) and another thirty to placebo group (B). Participants in group (A) received $50 \mathrm{mg} / \mathrm{kg} \mathrm{MgSO}_{4}$ in $100 \mathrm{ml}$ isotonic saline intravenous (IV) over 20 minutes prior to induction of general anesthesia by 30 minutes while participants in group (B) received 100 $\mathrm{ml}$ isotonic saline (placebo) by the same route and over the same duration as control. Results: Visual Analogue Scale (VAS) was analysed within 24 hours postoperatively. The mean pain score at 6 and 12 hours postoperatively was significantly lower in $\mathrm{MgSO}_{4}$ group compared to control group (40.4 \pm 5.12 vs $53.6 \pm 4.92 ; 26.1 \pm 3.01$ vs $35.5 \pm 3.98$ respectively, $\mathrm{p}=0.012,0.005)$. Comparing both groups regarding the mean time interval of first rescue analgesia (morphine sulphate) requested by the patients, it was longer in $\mathrm{MgSO}_{4}$ group compared to control group. The total dose of rescue analgesia consumed during 24 hours was analysed and it was significantly higher in control group compared to $\mathrm{MgSO}_{4}$ group (10.1 \pm 0.95 vs $\left.6.2 \pm 0.87, \mathrm{p}=0.001\right)$. Conclusion: We concluded that preoperative low doses $\left(50 \mathrm{mg} / \mathrm{Kg}\right.$ ) of $\mathrm{MgSO}_{4}$ with general anesthesia combined with ultrasound guided TAP block offer longer postoperative pain free periods thus reducing total opioid consumption. In addition to the safety of the drug to the mother and fetus so we recommend IV $\mathrm{MgSO}_{4}$ as an adjuvant therapy with TAP block.
\end{abstract}




\section{Keywords}

Transversus Abdominis Plane Block, Magnesium Sulphate, Postcesarean Analgesia, Rescue Analgesia

\section{Introduction}

Pain intensity and duration are elevated after central sensitization initiated by surgical incision and tissue damage. Start of preventive measures before incision and their implementation through the peri- and post-operative period, have a great impact in preventing the central sensitization, thereby ameliorating the acute pain, hyperalgesia and chronic pain [1] [2].

Preventive analgesia has been defined as an anti-nociceptive treatment that prevents establishment of altered central processing of afferent input from injuries. One of the intravenous adjuvants that have been shown potential in preventive analgesia is magnesium sulphate $\left(\mathrm{MgSO}_{4}\right)$ that could be administered with multiple routes or methods and one of those is preventive single low dose [3] [4] [5]. $\mathrm{MgSO}_{4}$ has been used for many years as an anticonvulsant or antiarrhythmic drug. The mechanism of the analgesic effect of $\mathrm{MgSO}_{4}$ is not clear but interference with calcium channels and N-methyl-D aspartate (NMDA) receptor seem to play an important role. The analgesic effect of NMDA-antagonists is made by inhibiting nociceptive central sensitization together with suggested reduction of catecholamine release with sympathetic stimulation, thereby decreasing peripheral nociception or the stress response to airway instrumentation and surgery [1] [6] [7] [8] [9] [10].

Cesarean section is one of the most commonly performed surgical procedures, it accounts for about $15 \%$ of births worldwide and $21.1 \%$ of those in the developed world [11]. The standard general anesthesia for cesarean section does not include opioid until after delivery of the fetus; this will lead eventually to increased risk of hypersensitisation, leading to increased post-operative acute pain and analgesia requirement [12]. Considering application of magnesium sulphate as preventive measures together with multimodal analgesic techniques maximizes the control of postoperative pain in the past few years [13].

The Transversus Abdominis Plane (TAP) Block is a local anesthetic block used to provide analgesia to the anterior and lateral abdominal wall. Rafi et al. [14] and McDonnell et al. [15] were the first to describe this novel abdominal field block. It blocks the mid/lower thoracic and upper lumbar spinal nerves as they travel in the fascial plane between the transversus abdominis and internal oblique muscles. Compared with placebo blocks, TAP block provided increased postoperative analgesia and decreased systemic medication requirements as part of a multimodal analgesic regimen for total abdominal hysterectomy [16], cesarean section [7], and laparoscopic cholecystectomy [17]. Moreover, guidance by ultrasound enriches this technique with more reliable efficacious treatment modality as it allows better localization and deposition of the local anesthetic 
with improved accuracy and reduced complications over the traditional anatomic landmark technique [16].

The aim of this study is to determine the role of preoperative low dose intravenous $\mathrm{MgSO}_{4}$ when given adjuvant to ultrasound guided transversus abdominis plane (TAP) block in augmenting postcesarean analgesic effects and reducing opioid requirements during the first 24 hours.

\section{Subjects and Methods}

\subsection{Study Design}

This is a prospective, randomized, double blind study carried out at Ibn Sina Medical College Hospital, Jeddah, Saudi Arabia from December 2015 till November 2016. Randomization was done with the help of a computer-generated list of numbers. A total of sixty full term pregnant women (completed 37 weeks) were recruited for the study underwent cesarean section. Thirty patients were assigned to $\mathrm{MgSO}_{4}$ group (A) and another thirty to placebo group (B). Group assignment, preparation and administration of drugs were performed by a nurse anesthetist who was neither involved nor interested by any means in the study. Blind grouping was kept to all including the patients themselves, until the completion of study. This study was approved by the Hospital Research Ethics Committee and has been performed in accordance with the ethical standards as in Declaration of Helsinki (1964) and its latter amendments, and a written informed consent was obtained from each participant prior to the study.

\subsection{Inclusion and Exclusion Criteria}

The inclusion criteria of these patients include class I-II according to American society of anaesthesiologists (ASA) physical status, singleton full term pregnancy subjected to cesarean section.

Exclusion criteria include; patients with ASA physical status class III-IV, morbid obesity with BMI $>35 \mathrm{kgm}^{-2}$ at initial hospital visit, neuro-axial anaesthesia, severe pre-eclampsia, diabetes mellitus, cardiovascular disease, renal disease, hypermagnesemia, history of analgesic administration or intake during past 24 hours, urgent cesarean sections, multiple gestations, history of relevant drug allergy, any possibility of anticipated difficult intubation.

Participants in group (A) received $50 \mathrm{mg} / \mathrm{kg} \mathrm{MgSO}_{4}$ in $100 \mathrm{ml}$ isotonic saline intravenous (I.V) over 20 minutes prior to induction of general anesthesia by 30 minutes while participants in group (B) received $100 \mathrm{ml}$ isotonic saline (placebo) by the same route and over the same duration as control.

\subsection{Preoperative Anesthetic Assessment}

All patients were subjected to a thorough medical history, physical examination, laboratory investigations (fasting blood sugar, kidney, liver function tests, serum electrolytes, coagulation profile, and electrocardiogram) preoperatively. They were also counselled about the anesthetic management and potential complications of both surgery and anesthesia, and the explanations of visual analogue 
scale (VAS) from 0 - 100. All these data were documented. A thorough airway assessment by Mallampati classification [18], mouth opening, neck movement, thyromental distance was done to find out any possibility of difficult intubation. If there was a chance of significant difficult intubation, the patient was excluded from the study.

\subsection{Anesthetic Protocol}

General anesthesia was induced with intravenous lignocaine $1.0 \mathrm{mg} / \mathrm{kg}$, propofol $2.0 \mathrm{mg} / \mathrm{kg}$, succinyl choline $1.0 \mathrm{mg} / \mathrm{Kg}$ then they were intubated and then atracurium $0.2 \mathrm{mg} / \mathrm{kg}$ was given for maintenance of muscle relaxation based on using a peripheral nerve stimulator. Anesthesia was continued by mixture of $\mathrm{O}_{2}$ and $\mathrm{N}_{2} \mathrm{O}$ along with $2 \%$ sevoflurane. After delivery of the fetus and placenta, 1 $\mathrm{mg}$ midazolam, $1 \mu \mathrm{g} / \mathrm{kg}$ fentanyl and $10 \mathrm{IU}$ oxytocin (in $500 \mathrm{ml}$ ringer solution) was administrated. Immediately after completion of surgery, each patient received ultrasound guided bilateral TAP blocks in the operating theatre. After that muscle relaxant was antagonized by $40 \mu \mathrm{g} / \mathrm{kg}$ neostigmine and $20 \mu \mathrm{g} / \mathrm{kg}$ atropine, then awake extubation was done and the patients were transferred to the recovery unit.

\subsection{Postoperative Analgesic Regimen}

It started in the recovery unit where patients received $16 \mathrm{mg}$ lornoxicam slowly IV over 5 minutes. After that all patients received acetaminophen $1 \mathrm{gm} / 6 \mathrm{~h}$ IV and $3 \mathrm{mg}$ morphine sulfate IV if breakthrough pain developed.

\subsection{Patients Assessment}

All patients were assessed for

1) Hemodynamic variables (heart rate, and mean arterial blood pressure) prior to anesthesia, post-intubation, post-extubation, and thirty minutes postoperative.

2) $\operatorname{VAS}(0=$ no pain, $1-30=$ mild pain, $40-60=$ moderate pain, $70-10=$ severe pain) at 2, 6, 12 and 24 hours postoperative.

3) Time elapsed till morphine is requested postoperatively for break through pain.

4) Total dose of rescue analgesia (morphine sulphate) used within the first 24 hours.

5) Time to ambulate the patient postoperatively.

6) APGAR scores at 1st and 5th minutes for neonates.

\subsection{TAP Block Technique}

Using an $18 \mathrm{G}$ Tuohy needle ( $80 \mathrm{~mm}$ Smiths medical Portex $\left.{ }^{\odot}\right)$ and the layers of the abdominal wall were identified guided by superficial high-frequency $45 \mathrm{~mm}$ linear array ultrasound probe $(13 \mathrm{MHz})$ as described by McDonnell and colleagues [15]. Twenty millilitre of $0.25 \%$ bupivacaine is injected slowly after careful aspiration to ensure no vascular injury has occurred. Successful injection 
produced an echo-lucent space between the muscle layers (internal oblique and transverses abdominis) (Figure 1).

All TAP blocks were performed by the same anesthetist and the operations by the same obstetrician.

\section{Statistical Analysis}

The Data was collected and entered into the personal computer. Statistical analysis was done using Statistical Package for Social Sciences (SPSS/version 20) software. Arithmetic mean, standard deviation, t-test was used to compare the two groups. The level of significance was 0.05 .

Sample size calculation: Sample size was calculated by using Med Calc statistical software. Assuming area under ROC to be 0.80 , an alpha of 0.05 and power of study $90.0 \%$. A minimum sample size required was calculated to be 30 patients in each group for this study.

\section{Results}

This is a prospective, randomized, double blind study. A total of sixty consented full term pregnant women were classified into two groups, $\mathrm{MgSO}_{4}$ group $(N=$ $30)$, and placebo group $(N=30)$ all participants completed the trial. The demographic characteristics of the study participants are illustrated in Table 1. There were no statistically significant differences between the two groups regarding maternal age, body mass index (BMI), gestational age, and parity. Furthermore, there were also no statistically significant differences between the two groups regarding duration of anesthesia, duration surgery, estimated blood loss, and Apgar score of neonates as well (Table 1).

Regarding Hemodynamic variables of patients, the mean pre-anesthetic heart rate and MAP showed statistically insignificant difference between both groups $(\mathrm{P}=0.098,0.068$ respectively). The mean post-intubation and post-extubation

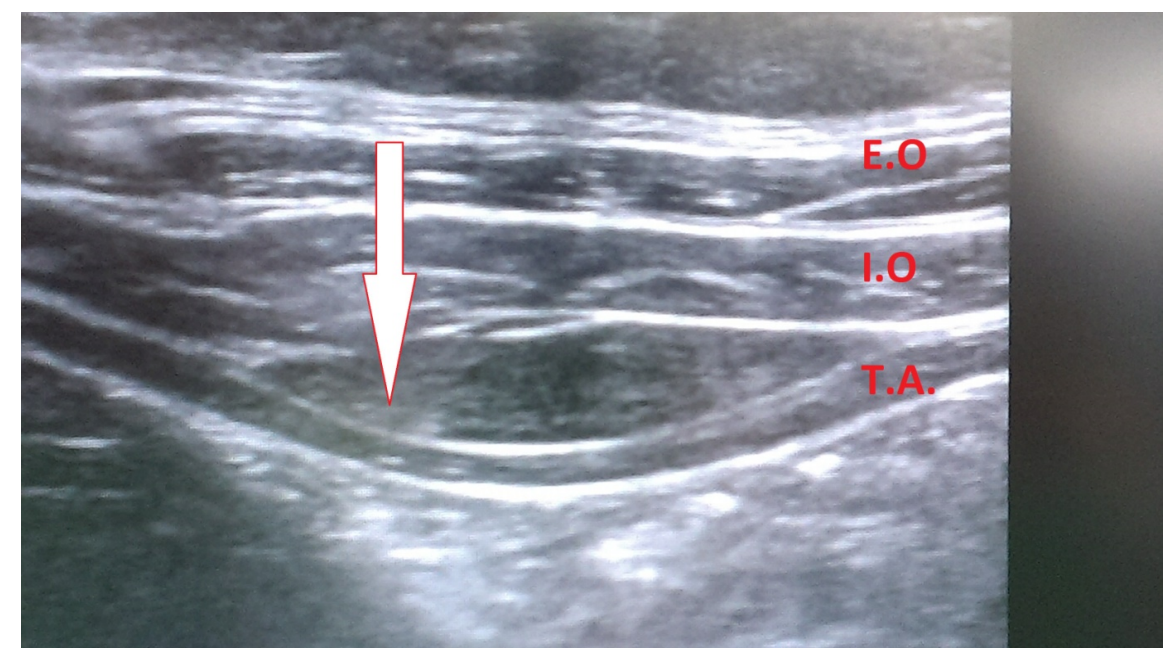

Figure 1. Anterior abdominal wall view during injection of local anesthesia. E.O. External Oblique, I.O. Internal Oblique, T.A. Transversus Abdominis and the arrow point to the echolucent image of local anesthesia injected. 
Table 1. The demographic data and clinical characteristic of Patients in group (A), and group (B).

\begin{tabular}{|c|c|c|c|}
\hline Variables & $\begin{array}{l}\mathrm{TAB}+\mathrm{MgSO}_{4} \\
(\text { Group } \mathrm{A}=30)\end{array}$ & $\begin{array}{c}\text { TAB } \\
(\text { Group } B=30)\end{array}$ & $\mathrm{p}$ \\
\hline $\begin{array}{l}\text { Age (years) } \\
\text { Mean } \pm \text { S.D }\end{array}$ & $28.2 \pm 4.33$ & $27.4 \pm 3.02$ & 0.4211 \\
\hline $\begin{array}{l}\text { BMI }\left(\mathrm{Kg} / \mathrm{m}^{2}\right) \\
\text { Mean } \pm \text { S.D }\end{array}$ & $26.2 \pm 2.25$ & $27.1 \pm 1.98$ & 0.526 \\
\hline $\begin{array}{l}\text { Gestational age (weeks) } \\
\text { Mean } \pm \text { S.D }\end{array}$ & $37.9 \pm 0.67$ & $38.3 \pm 0.48$ & 0.458 \\
\hline $\begin{array}{c}\text { Parity } \\
\text { Mean } \pm \text { S.D }\end{array}$ & $2.1 \pm 0.58$ & $2.2 \pm 0.78$ & 0.401 \\
\hline $\begin{array}{c}\text { Duration of Surgery (minutes) } \\
\text { Mean } \pm \text { S.D }\end{array}$ & $43.6 \pm 3.2$ & $48.2 \pm 4.22$ & 0.136 \\
\hline \multicolumn{4}{|l|}{ APGAR Score } \\
\hline $\begin{array}{l}1^{\text {st }} \text { Minute } \\
\text { Mean } \pm \text { S.D }\end{array}$ & $8.1 \pm 0.89$ & $8.3 \pm 0.74$ & 0.352 \\
\hline $\begin{array}{l}5 \text { Minutes } \\
\text { Mean } \pm \text { S.D }\end{array}$ & $9.4 \pm 1.03$ & $9.7 \pm 1.11$ & 0.625 \\
\hline $\begin{array}{c}\text { Duration of Anesthesia (minutes) } \\
\text { Mean } \pm \text { S.D }\end{array}$ & $54 \pm 6.25$ & $56 \pm 7.01$ & 0.558 \\
\hline $\begin{array}{c}\text { Estimated blood loss }(\mathrm{ml}) \\
\text { Mean } \pm \text { S.D }\end{array}$ & $570 \pm 162.3$ & $520 \pm 207.6$ & 0.107 \\
\hline
\end{tabular}

Data are presented as mean $\pm \mathrm{SD}$; TAB: transverses abdominis plain block; $\mathrm{MgSO}_{4}$ : magnesium sulphate; BMI: Body mass index; ${ }^{\star}$ Significant.

heart rate was significantly higher in group (B) compared to group (A) (91.2 \pm 5.98 vs $85.1 \pm 7.32 ; 100.3 \pm 6.22$ vs $90.1 \pm 6.21$ respectively; $\mathrm{P}=0.011,0.005)$. While, the mean heart rate showed insignificant difference between both groups $(\mathrm{P}=0.067) 30$ minutes postoperatively. On the other hand the MAP was statistically significant higher with respect to post-intubation, and post-extubation readings in group (B) compared to group (A) $(\mathrm{P}=0.035,0.017$ respectively). While the MAP showed statistically insignificant difference between both groups ( $\mathrm{P}=0.065) 30$ minutes postoperatively (Table 2).

VAS was analysed within 24 hours postoperatively. The mean pain score at 2 hours postoperatively showed statistically insignificant difference between both groups $(\mathrm{P}=0.071)$. While it was statistically significant lower in $\mathrm{MgSO}_{4}$ group compared to control group at 6,12 hours postoperatively ( $40.4 \pm 5.12$ vs $53.6 \pm$ $4.92 ; 26.1 \pm 3.01$ vs $35.5 \pm 3.98$ respectively, $\mathrm{p}=0.012,0.005$ ). Twenty four hours postoperatively, the mean VAS showed statistically insignificant difference between both groups $(\mathrm{p}=0.655)$ (Table 3$)$.

Comparing both groups regarding the mean time interval of first rescue analgesia (morphine sulphate) requested by the patients, it was longer in $\mathrm{MgSO}_{4}$ group compared to control group (200.2 \pm 16.5 vs $120 \pm 11.65, \mathrm{p}=0.002)$. The total dose of rescue analgesia consumed during 24 hours was analysed and it was 
Table 2. Hemodynamic status in patients in group (A), and group (B).

\begin{tabular}{|c|c|c|c|c|c|c|}
\hline \multirow{2}{*}{ Variables } & \multicolumn{3}{|c|}{ HR bpm } & \multicolumn{3}{|c|}{ MAP (mmHg) } \\
\hline & $\begin{array}{c}\mathrm{TAB}+\mathrm{MgSO}_{4} \\
(\text { Group } \mathrm{A}=30)\end{array}$ & $\begin{array}{c}\text { TAB } \\
(\text { Group B }=30)\end{array}$ & $\mathrm{p}$ & $\begin{array}{c}\mathrm{TAB}+\mathrm{MgSO}_{4} \\
(\text { Group } \mathrm{A}=30)\end{array}$ & $\begin{array}{c}\text { TAB } \\
(\text { Group } \mathrm{B}=30)\end{array}$ & $\mathrm{p}$ \\
\hline $\begin{array}{c}\text { Pre-anesthetic } \\
\text { Mean } \pm \text { S.D }\end{array}$ & $82.9 \pm 9.65$ & $87.1 \pm 6.23$ & 0.098 & $72.4 \pm 6.89$ & $78.1 \pm 6.45$ & 0.068 \\
\hline $\begin{array}{l}\text { Post Intubation } \\
\text { Mean } \pm \text { S.D }\end{array}$ & $85.1 \pm 7.32$ & $91.2 \pm 5.98$ & $0.011^{*}$ & $82.1 \pm 6.52$ & $89.3 \pm 7.01$ & $0.035^{\star}$ \\
\hline $\begin{array}{c}\text { Post Extubation } \\
\text { Mean } \pm \text { S.D }\end{array}$ & $90.1 \pm 6.21$ & $100.3 \pm 6.22$ & $0.005^{\star}$ & $83.2 \pm 7.23$ & $91.4 \pm 8.25$ & $0.017^{\star}$ \\
\hline $\begin{array}{l}30 \text { minutes in } \\
\text { Recovery Room } \\
\text { Mean } \pm \text { S.D }\end{array}$ & $84.2 \pm 10.2$ & $90.1 \pm 7.05$ & 0.067 & $84.1 \pm 5.21$ & $90.3 \pm 8.21$ & 0.065 \\
\hline
\end{tabular}

Data are presented as mean $\pm \mathrm{SD}$; $\mathrm{TAB}$ : transverses abdominis plain block; $\mathrm{MgSO}_{4}$ : magnesium sulphate; HR: heart rate, bpm: beat per minute; MAP: mean arterial pressure; mmHg: millimetre mercury; *Significant.

Table 3. Postoperative Visual analogue score (VAS) in patients of group (A), and group (B).

\begin{tabular}{cccc}
\hline $\begin{array}{c}\text { Pain Score } \\
\text { VAS }(0-100)\end{array}$ & $\begin{array}{c}\mathrm{TAB}+\mathrm{MgSO}_{4} \\
(\mathrm{Group} \mathrm{A}=30)\end{array}$ & $\begin{array}{c}\mathrm{TAB} \\
(\text { Group B }=30)\end{array}$ & $\mathrm{p}$ \\
\hline $\begin{array}{c}2 \text { hours } \\
\text { Mean } \pm \text { S.D } \\
6 \text { hours }\end{array}$ & $51.3 \pm 9.22$ & $58.7 \pm 8.22$ & 0.071 \\
Mean \pm S.D & $40.4 \pm 5.12$ & $53.6 \pm 4.92$ & $0.012^{*}$ \\
$\begin{array}{c}12 \text { hours } \\
\text { Mean } \pm \text { S.D }\end{array}$ & $26.1 \pm 3.01$ & $35.5 \pm 3.98$ & $0.005^{*}$ \\
$\begin{array}{c}24 \text { hours } \\
\text { Mean } \pm \text { S.D }\end{array}$ & $23.3 \pm 2.46$ & $24.2 \pm 6.02$ & 0.655 \\
\hline
\end{tabular}

Data are presented as mean $\pm \mathrm{SD}$; $\mathrm{TAB}$ : transverses abdominis plain block; $\mathrm{MgSO}_{4}$ : magnesium sulphate; *Significant.

significantly higher in control group $(10.1 \pm 0.95)$ compared to $\mathrm{MgSO}_{4}$ group $(6.2 \pm 0.87)$ and the p-value was (0.001). Moreover, the mean time needed for the patients to ambulate independently was significantly longer in control group $(6.3 \pm 0.97 \mathrm{hr})$ compared to $\mathrm{MgSO}_{4}$ group (4.2 \pm 0.89$)$ and $\mathrm{p}$ value was $(0.0041)$ (Table 4).

\section{Discussion}

Patients undergoing cesarean sections with general anesthesia routinely experience noxious stimuli during laryngoscopy, intubation and abdominal incision prior to fetal delivery, during which they do not receive adequate analgesia due to fetal concerns. Therefore central sensitization occurs, leading to increased probability of acute and chronic post-operative pain [7].

$\mathrm{MgSO}_{4}$ is an intracellular cation acts as a calcium channels antagonist and as noncompetitive NMDA receptors antagonist [19]. Thus preventing central and peripheral sensitization caused by noxious stimuli. $\mathrm{MgSO}_{4}$ acts as preventive 
Table 4. Postoperative rescue analgesic requirements, and time to ambulate in patients in group (A) and Group (B).

\begin{tabular}{cccc}
\hline & $\begin{array}{c}\mathrm{TAB}+\mathrm{MgSO}_{4} \\
(\text { Group } \mathrm{A}=30)\end{array}$ & $\begin{array}{c}\mathrm{TAB} \\
(\text { Group B }=30)\end{array}$ & $\mathrm{p}$ \\
\hline $\begin{array}{c}\text { Interval of } 1^{\text {st }} \text { Analgesic } \\
\text { Requirement (minute) } \\
\text { Mean } \pm \text { S.D }\end{array}$ & $200.2 \pm 16.5$ & $120 \pm 11.65$ & $0.0025^{*}$ \\
$\begin{array}{c}\text { Total Dose of Rescue Analgesics } \\
\text { (Morphine Sulfate) (mg) } \\
\text { Mean } \pm \text { S.D } \\
\text { Time to Ambulate } \\
\text { Unassisted (hours) } \\
\text { Mean } \pm \text { S.D }\end{array}$ & $6.2 \pm 0.87$ & $10.1 \pm 0.95$ & $0.001^{*}$ \\
& & & \\
\hline
\end{tabular}

Data are presented as mean $\pm \mathrm{SD}$; $\mathrm{TAB}$ : transverses abdominis plain block; $\mathrm{MgSO}_{4}$ : magnesium sulphate; ${ }^{*}$ Significant.

analgesic and may have a role in prevention of post-operative pain [20] [21]. TAP block could be used effectively as a part of postcesarean section multimodal analgesia as it provides good analgesia with opioid-sparing comparable to that provided by intrathecal morphine [22] [23] [24].

Many studies assessed the perioperative analgesic effect of $\mathrm{MgSO}_{4}$. Mavrommati and colleagues reported that low dose $\mathrm{MgSO}_{4}$ infusion in hernioplasty was an effective adjuvant for perioperative analgesic management [25]. Likewise, Ryu and colleagues in a randomized double-blinded study reported that $\mathrm{MgSO}_{4}$ in a bolus dose of $50 \mathrm{mg} / \mathrm{kg}$, followed by $15 \mathrm{mg} / \mathrm{kg} / \mathrm{h}$ was effective in reducing postoperative analgesia and VAS in gynaecologic surgery patients underwent total intravenous anaesthesia (TIVA) [4]. The same conclusions were supported by Lee and colleague [26], Kiran and colleagues who also reported that IV $\mathrm{MgSO}_{4}$ could decrease postoperative pain and equivalent of rescue analgesia [27].

Recently, Sayed et al. studied the administration of $50 \mathrm{mg} / \mathrm{kg}$ IV bolus $\mathrm{MgSO}_{4}$ prior to induction of general anesthesia in elective cesarean candidates, and they concluded that it could curtail the acute postoperative pain and has sparing effects on morphine requirement during first 24 hrs [28]. Another similar study done by Arman T. and colleagues [29] who used low dose of $\mathrm{MgSO}_{4}$ prior to induction of balanced general anesthesia for total abdominal hysterectomy (TAH), concluded that $\mathrm{MgSO}_{4}$ alleviate postoperative pain throughout the first day after TAH significantly and reduce opioid consumption as well. On the contrary, Lysakowski and colleagues in a systemic randomized trial found no convincing evidence about the valuable benefits of perioperative $\mathrm{MgSO}_{4}$ on postoperative pain intensity and analgesic requirement [30].

In our study we investigated IV low dose $\mathrm{MgSO}_{4}(50 \mathrm{mg} / \mathrm{kg})$ combined with TAP block in order to intensify the potency and duration of analgesia, thus reducing the required doses of opioids postoperatively and allows early ambulation and consequently reducing hospital stay and total patient costs. We documented that VAS score at 6 and 12 hours postoperatively was significantly lower 
in $\mathrm{MgSO}_{4}$ group compared to placebo group, while the VAS score at 24 hours was insignificant between both groups. The total dose of rescue analgesia consumed during 24 hours was significantly lower in $\mathrm{MgSO}_{4}$ group compared to control. Therefore, the analgesic effect of $\mathrm{MgSO}_{4}$ is maximally effective during the first 12 hours, and our results are in agreement with the previously mentioned studies [25] [26] [27] [28] [29].

Hypotensive effect of $\mathrm{MgSO}_{4}$ explained with its direct vasodilatation effect through the calcium channel blockade and rarely observed up to $60 \mathrm{mg} / \mathrm{kg}$ [3] [31]. Regarding Hemodynamic variables, in the current study although the postintubation and postextubation heart rate and MAP were significantly lower in $\mathrm{MgSO}_{4}$ group compared to placebo, we didn't record any significant hypotensive episodes with $\mathrm{MgSO}_{4}$. This could be explained by the role of $\mathrm{MgSO}_{4}$ on reduction of catecholamine release with sympathetic stimulation, thereby decreasing the stress response to intubation and surgery, in addition to that we even used lower doses than $60 \mathrm{mg} / \mathrm{kg}$. No maternal complications encountered in either group, and the 1st and 5th minutes APGAR scores in all newborns were normal and showed insignificant difference between both groups which reflects the safety of perioperative $\mathrm{MgSO}_{4}$ infusion on the mother and fetus.

\section{Study Limitation}

Our study had some limitations such as; sample collection for this study requires accurate patient selection based on inclusion and exclusion criteria particularly the body mass index because obesity offers technical challenging difficulty for ultrasound guided TAP block. In addition, smaller sample size hence our findings still need more interpretation for further study. This should be addressed by future prospective studies to verify and clarify the role of $\mathrm{MgSO}_{4}$ as an adjuvant analgesic with local nerve blocks.

\section{Conclusion}

We concluded that preoperative low doses $\left(50 \mathrm{mg} / \mathrm{Kg}\right.$ ) of $\mathrm{MgSO}_{4}$ with general anesthesia combined with Ultrasound guided TAP block offer longer postoperative pain free periods thus reducing total opioid consumption. In addition to the safety of the drug to the mother and fetus so we recommend IV $\mathrm{MgSO}_{4}$ as an adjuvant therapy with TAP block.

\section{Declaration of Funding}

This study was not funded.

\section{Conflict of Interest}

The authors declare that they have no conflict of interest.

\section{References}

[1] Kissin, I. (2000) Preemptive Analgesia. Anesthesiology, 93, 1138-1143. https://doi.org/10.1097/00000542-200010000-00040 
[2] Wolf, C.J. and Thompson, S.W. (1991) Sensitization Is Dependent on Acid Receptor Activation; Implications for the Treatment of Post-Injury Pain Hypersensitivity States. Pain, 44, 293-299. https://doi.org/10.1016/0304-3959(91)90100-C

[3] Miller, R.D. (2015) Miller's Anesthesia. 8th Edition, Churchil Livingstone, San Diego, 31 .

[4] Ryu, J.-H., Kang, M.-H., Park, K.-S. and Do, S.H. (2008) Effects of Magnesium Sulphate on Intraoperative Anaesthetic Requirements and Postoperative Analgesia in Gynaecology Patients Receiving Total Intravenous Anaesthesia. British Journal of Anaesthesia, 100, 397-403. https://dx.doi.org/10.1093/bja/aem407

[5] Dabbagh, A., Elyasi, H., Razavi, S.S., Fathi, M. and Rajaei, S. (2009) Intravenous Magnesium Sulfate for Post-Operative Pain in Patients Undergoing Lower Limb Orthopedic Surgery. Acta Anaesthesiologica Scandinavica, 53, 1088-1091. https://dx.doi.org/10.1111/j.1399-6576.2009.02025.x

[6] Hines, R.L. and Marchall, K.E. (2012) Stoelting's Anesthesia and Co-Existing Disease. 6th Edition, vol. 18, Elsevier, New York.

[7] Tramer, M.R., Schneider, J., Marti, R.A. and Rifat, K. (1996) Role of Magnesium Sulfate in Postoperative Analgesia. Anesthesiology, 84, 340-347.

https://doi.org/10.1097/00000542-199602000-00011

[8] Hwang, J.Y., Na, H.S., Jeon, Y.T., Ro, Y.J., Kim, C.S. and Do, S.H. (2010) I.V. Infusion of Magnesium Sulphate during Spinal Anaesthesia Improves Postoperative Analgesia. British Journal of Anaesthesia, 104, 89-93. https://dx.doi.org/10.1093/bja/aep334

[9] Alavi, S.M., Baharestani, B., Farsad, B.F. Bakhshandeh, H., Babaee, T., Sadeghpur, A., et al. (2011) Intraoperative Magnesium Sulfate Can Reduce Narcotic Requirement after Coronary Bypass Surgery. The Iranian Journal of Cardiac Surgery, 12, 32-35.

[10] Haryalchi, K., Ghanaie, M.M., Yaghoubi, Y., Milani, F. and Faraji, R. (2013) An Assessment of Changes in Magnesium Level during Gynaecological Abdominal Surgeries. Journal of Basic and Clinical Reproductive Sciences, 2, 98-102. http://dx.doi.org/10.4103/2278-960X.118654

[11] Betran, A.P., Merialdi, M., Lauer, J.A., Bing-Shun, W., Thomas, J., Van Look, P., et al. (2007) Rates of Caesarean Section: Analysis of Global, Regional and National Estimates. Paediatric and Perinatal Epidemiology, 21, 98-113. https://dx.doi.org/10.1111/j.1365-3016.2007.00786.x

[12] Ghazi-Saidi, K. and Hajipour, A. (2002) Effects of Preemptive Ketamine on Post-Cesarean Analgesic Equirement. Acta Medica Iranica, 40, 100-103.

[13] Xiao, W.H. and Bennett, G.J. (1994) Magnesium Suppresses Neuropathic Pain Responses in Rats via a Spinal Site of Action. Brain Research, 666, 168-172.

[14] Rafi, A.N. (2001) Abdominal Field Block: A New Approach via the Lumbar Triangle. Anaesthesia, 56, 1024-1026.

[15] McDonnell, J.G., O’Donnell, B.D., Tuite, D. Farrell, T. and Power, C. (2004) The Regional Abdominal Field Infiltration Technique Computerised Tomographic and Anatomical Identification of a Novel Approach to the Transversus Abdominis Neuro-Vascular Fascial Plane. Anaesthesiology, 101, A899.

[16] Hebbard, P., Fujiwara, Y., Shibata, Y. and Royse, C. (2007) Ultrasound Guided Transversus Abdominis Plane Block. Anaesthesia \& Intensive Care, 35, 616-617.

[17] El-Dawlatly, A.A., Turkistani, A., Kettner, S.C., Machata, A.M., Delvi, M.B.,Thallaj, A., et al. (2009) Ultrasound-Guided Transversus Abdominis Plane Block: Description of a New Technique and Comparison with Conventional Systemic Analgesia 
during Laparoscopic Cholecystectomy. British Journal of Anaesthesia, 102, 763-767. https://dx.doi.org/10.1093/bja/aep067

[18] Mallampati, S.R., Gatt, S.P., Gugino, L.D., Waraksa, B., Freiburger, D. and Liu, P.L. (1985) A Clinical Sign to Predict Difficult Intubation; A Prospective Study. Canadian Anaesthetists' Society Journal, 32, 429-434. https://doi.org/10.1007/BF03011357

[19] Iseri, L.T. and French, J.H. (1984) Magnesium: Nature's Physiologic Calcium Blocker. American Heart Journal, 108, 188-193. http://dx.doi.org/10.1016/0002-8703(84)90572-6

[20] Woolf, C.J. and Thomson, S.W. (1991) The Induction and Maintenance of Central Sensitization Is Dependent on Acid Receptor Activation; Implications for the Treatment of Post Injury Pain Hypersensitivity States. Pain, 44, 293-299. https://doi.org/10.1016/0304-3959(91)90100-C

[21] Mayer, M.L., Westbrook, G.L. and Guthrie, P.B. (1984) Voltage Dependent Block by $\mathrm{Mg}+{ }^{2}$ of NMDA Responses in Spinal Cord Neurons. Nature, 309, 261-263. https://doi.org/10.1038/309261a0

[22] McDonnell, J.G., Curley, G., Carney, K., Benton, A., Costello, J., Maharaj, C.H., et al. (2008) The Analgesic Efficacy of Transversus Abdominis Plane Block after Caesarean Section Delivery: A Randomised Controlled Trial. Anesthesia \& Analgesia, 106, 186-191. https://dx.doi.org/10.1213/01.ane.0000290294.64090.f3

[23] Belavy, D., Cowlishaw, P.J., Howes, M. and Phillips, F. (2009) Ultrasound-Guided Transversus Abdominis Plane Block for Analgesia after Caesarean Delivery. British Journal of Anaesthesia, 103, 726-730. https://dx.doi.org/10.1093/bja/aep235

[24] McMorrow, R., Mhuircheartaigh, R.N., Ahmed, K., Aslani, A., Ng, S.C., ConrickMartin, I., et al. (2011) Comparison of Transversus Abdominis Plane Block VS Spinal Morphine for Pain Relief after Caesarean Section. British Journal of Anaesthesia, 106, 706-712. https://dx.doi.org/10.1093/bja/aer061

[25] Mavrommati, P.D., Gabopoulou, Z.T., Papadimos, C.N., Petsikopoulos, M.G., Vrettou, V.A., Konstntinidou, M.G., et al. (2004) The Perioperative Infusion of Low Doses of Magnesium Sulfate Reduces Analgesic Requirements in Patients Undergoing Abdominal Hernioplasty. Acute Pain, 5, 81-87.

[26] Lee, D.H. and Kwon, I.C. (2009) Magnesium Sulphate Has Beneficial Effects as an Adjuvant during General Anaesthesia for Caesarean Section. British Journal of Anaesthesia, 103, 861-866. https://dx.doi.org/10.1093/bja/aep265

[27] Kiran, S., Gupta, R. and Verma, D. (2011) Evaluation of a Single Dose of Intravenous Magnesium Sulphate for Prevention of Postoperative Pain after Inguinal Surgery. Indian Journal of Anaesthesia, 55, 31-35. https://dx.doi.org/10.4103\%2F0019-5049.76605

[28] Seyed, M., Khalil, P., Asghar, H., Afshin, J., Shahram, S. and Omid, N. (2015) Effects of Preoperative Magnesium Sulphate on Post-Cesarean Pain, a Placebo Controlled Double Blind Study. Journal of Family and Reproductive Health, 9, 29-33.

[29] Arman, T., Katayoun, H., Mandana, M.G. and Neda, H.A. (2015) Effect of Low-Dose (Single-Dose) Magnesium Sulfate on Postoperative Analgesia in Hysterectomy Patients Receiving Balanced General Anesthesia. Anesthesiology Research and Practice, 5, 1-6. http://dx.doi.org/10.1155/2015/306145

[30] Lysakowski, C., Dumont, L., Czarnetzki, C. and Tramer, M. (2007) Magnesium as an Adjuvant to Postoperative Analgesia: A Systematic Review of Randomized Trials. Anesthesia and Analgesia, 104, 1532-1539.

https://dx.doi.org/10.1213/01.ane.0000261250.59984.cd 
[31] Albrecht, E., Kirkham, K.R., Liu, S.S. and Brull, R. (2013) Perioperative Intravenous Administration of Magnesium Sulphate and Postoperative Pain: A Meta-Analysis. Anaesthesia, 68, 79-90. https://dx.doi.org/10.1111/j.1365-2044.2012.07335.x

Submit or recommend next manuscript to SCIRP and we will provide best service for you:

Accepting pre-submission inquiries through Email, Facebook, LinkedIn, Twitter, etc. A wide selection of journals (inclusive of 9 subjects, more than 200 journals)

Providing 24-hour high-quality service

User-friendly online submission system

Fair and swift peer-review system

Efficient typesetting and proofreading procedure

Display of the result of downloads and visits, as well as the number of cited articles

Maximum dissemination of your research work

Submit your manuscript at: http://papersubmission.scirp.org/

Or contact ojog@scirp.org 